PALEO

Revue d'archéologie préhistorique

$30-2 \mid 2020$

Varia

\title{
The elk/moose (Alces alces) in the Upper Palaeolithic Art of Western Europe
}

L'Élan (Alces alces) dans l'art du Paléolithique supérieur de l'Europe occidentale

Ingmar M. Braun

\section{OpenEdition}

Journals

Electronic version

URL: http://journals.openedition.org/paleo/5126

DOI: $10.4000 /$ paleo.5126

ISSN: $2101-0420$

\section{Publisher}

SAMRA

Printed version

Date of publication: 1 September 2020

Number of pages: $58-74$

ISSN: $1145-3370$

\section{Electronic reference}

Ingmar M. Braun, «The elk/moose (Alces alces) in the Upper Palaeolithic Art of Western Europe », PALEO [Online], 30-2 | 2020, Online since 30 September 2020, connection on 26 November 2020. URL : http://journals.openedition.org/paleo/5126 ; DOI : https://doi.org/10.4000/paleo.5126

\section{cc) (i) (2)}

PALEO est mis à disposition selon les termes de la licence Creative Commons Attribution - Pas d'Utilisation Commerciale - Pas de Modification 4.0 International. 
THE ELK/MOOSE

(ALCES ALCES) IN THE

UPPER PALAEOLITHIC

ART OF WESTERN

EUROPE

Ingmar M. Brauna

a. Wyhlenweg 4; CH-4126 Bettingen (Suisse); ingmarbraun@gmx.ch ; www.palaeolithikum.com
The elk (Alces alces) - moose in American English belongs to the family Cervidae and is within this family the largest species. After the European bison (Bison bonasus) it is the biggest land mammal of Europe. Although it had a large distribution area during the last glacial period its fossil remains are rare. It is therefore not surprising that the elk was rarely represented in Upper Palaeolithic art (cave and portable art). The following article describes the few definite and potential representations of elk in Western European Upper Palaeolithic art.

PALEO 30 | $\mathrm{t} .2$

JUILET 2020

PAGES 58 À 74

KEY-WORDS Elk/Moose, Contemporary elk/moose, Fossil elk/moose, Upper Palaeolithic, Cave Art, Portable Art. 
L'Élan (Alces alces) dans l'art du Paléolithique supérieur de l'Europe occidentale.

L'élan (Alces alces appartient à la famille des cervidés et forme dans cette famille la plus grande espèce. Après le bison d'Europe (Bison bonasus), l'élan est le plus grand mammifère terrestre d'Europe. Bien qu'il ait eu une grande aire de répartition au cours de la dernière période glaciaire, ses restes fossiles sont rares. Il n'est donc pas surprenant que l'élan ait été rarement représenté dans l'art paléolithique supérieur (art pariétal et art mobilier). L'article suivant décrit les quelques représentations précises et potentielles de l'élan dans l'art du Paléolithique supérieur de l'Europe occidentale.

\section{INTRODUCTION}

Upper Palaeolithic art is characterised by the often very realistic depictions of animals. Among the depicted animals especially the group of herbivores is dominant. Elks (moose in American English) are rare as fossil remains - also in the Upper Palaeolithic layers - although they had a large geographical distribution area during the last glacial period («Würm») in Europe (Kahlke 1994). There are only a few representations of the elk in the Western European Upper Palaeolithic art. Some of them can only be interpreted as potential elk representations. Before the figures are described, the contemporary elk and its main characteristics are mentioned. Then a short chapter about the fossil elks follows. The main part of this paper is dedicated to the representations of the elk in the Western European Upper Palaeolithic cave and portable art.

\section{1 | THE CONTEMPORARY ELK (ALCES ALCES)}

\section{1 | General information}

The elk (Alces alces) belongs to the family Cervidae (fig.1). Within this family it is the largest species and, after the bison (Bison bonasus), the second biggest land mammal in Europe (Nygrén 1986). Their body length is between $200-300 \mathrm{~cm}$, their shoulder height between $150-220 \mathrm{~cm}$ and their tail between $7-10 \mathrm{~cm}$ long. With $20-35 \mathrm{~cm}$ the ears are very long and they are broad and oblong oval shaped. Elks have very long legs. The distinctive withers form a clearly visible hump on the back line. The head is very elongated and correspondingly large. Due to the strongly hanging upper lip, the forehead-nose-line is clearly arched. This gives the elk its typical curved head shape. Morphologically the head shape of elk is similar to that of the saiga. The large nostrils, however, are directed forward in contrast to the saiga. At a certain age a kind of "beard" forms with both sexes (fig. 2) (Heptner and Nasimowitsch 1967 ; Nygrén 1986 ; Reichholf 1982). As with the other species of the family Cervidae - with exception of the reindeer - only the male animals carry an antler starting from a certain age (see 1.2 - The antlers).

Nowadays elks have a large distribution area, which extends from Europe via Russia to North America. In Europe they occur mainly in the Scandinavian countries Finland, Norway and Sweden (Nygrén 1986 ; Reichholf 1982). Elks prefer deciduous and mixed forests and areas with lakes, swamps and bogs as biotopes (Heptner and Nasimowitsch 1967 ; Nygrén 1986 ; Reichholf 1982). Even though elks are land mammals, they can swim very well (Reichholf 1982).

\section{2 | The antlers}

The characteristic feature of male elks are their palmate antlers, which can be very broad and have several tines (fig. 3a, 3b and fig. 4A). However, there are also elks, which have only simple beam antlers (fig.3c and fig. 4B). According to Reichholf (1982) this is so with weaker and younger animals. As a rule the development of the palmate antlers takes place as follows: According to Nygrén (1986) and Heptner and Nasimowitsch (1967) elks usually have antlers in the form of a short skewer in the second year of life. In 

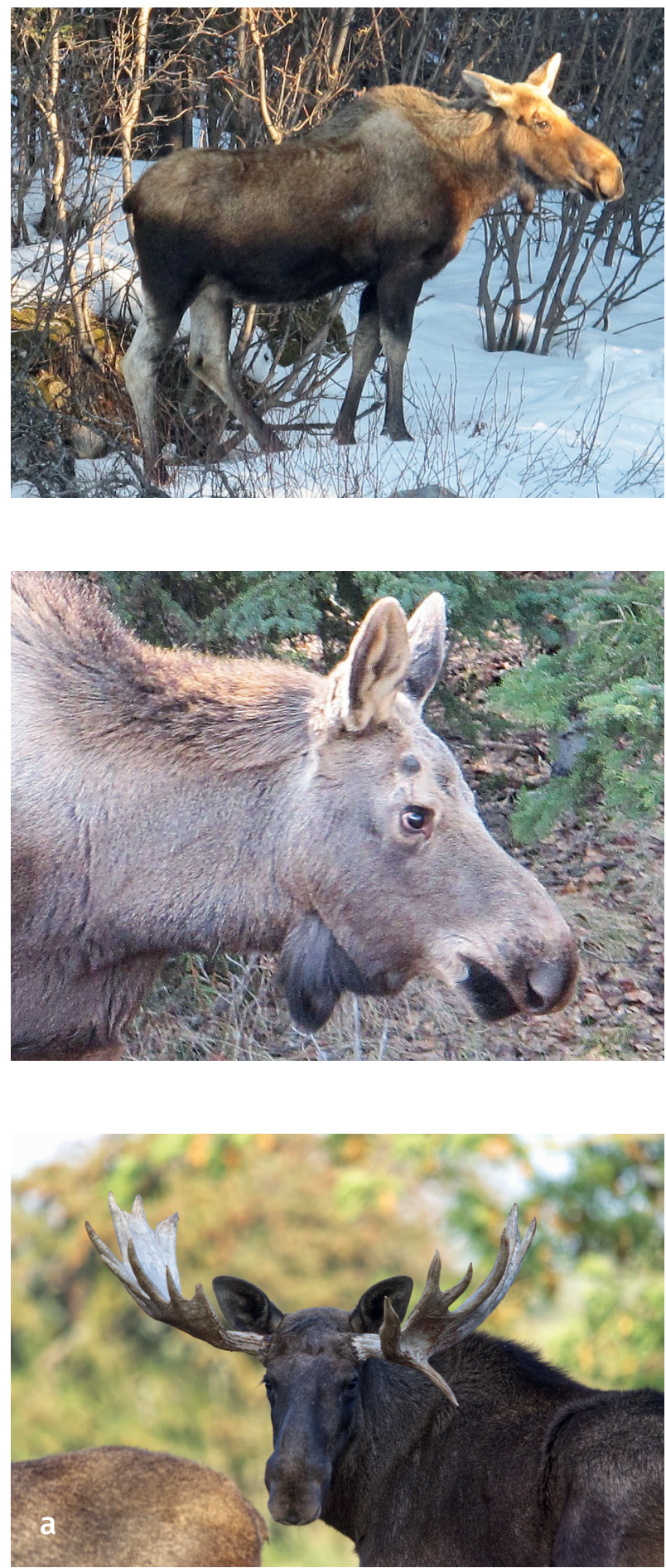

\section{- FIGURE 3a and $b$ -}

Male elk with the typical palmate antlers from the front (a) and from the side (b). (Photo and ๑ Elch \& Rentierfarm Th. Golz, www.wild-golz.de).

Élan mâle avec les bois palmés typiques de l'avant (a) et du côté (b). (Photo et

( ) Elch \& Rentierfarm Th. Golz, www.wild-golz.de).

the third year the antlers consist of a fork with two ends and in the fourth year of a beam with three tines. The typical palmate antler only begins to grow after these stages. The number of tines varies from animal to animal and there can be up to 18 tines or even more per side. The climax of the antler-development is between the fifth and tenth year. Afterwards the growth of the antlers decreases. However, Nygrén (1986) emphasizes that antler formation

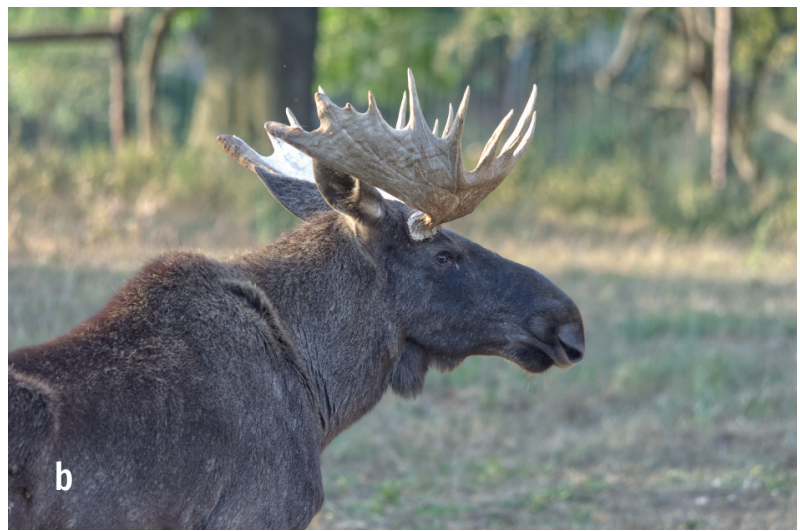

\section{FIGURE 1}

Female elk in Alaska (Photo I. M. Braun).

Élan femelle en Alaska (Photo I. M. Braun).

\section{FIGURE 2}

Head of an elk in Alaska with the characteristic curved shape, the large nostrils directed forward, the "beard" and the long ears (Photo I. M. Braun).

Tête d'élan en Alaska avec la forme busquée caractéristique, les grandes narines dirigées vers l'avant, la «barbe» et les longues oreilles (Photo I. M. Braun).

- apart from the first stage - can be very different and that deviations can occur frequently. It is therefore very unreliable as an age determination.

As with the other species of the family Cervidae the antlers are thrown off once a year. Depending on the age of the animal the antlers are thrown off at different times. According to Nygrén (1986) older animals throw off their antlers between October and February, two-year-old deer 

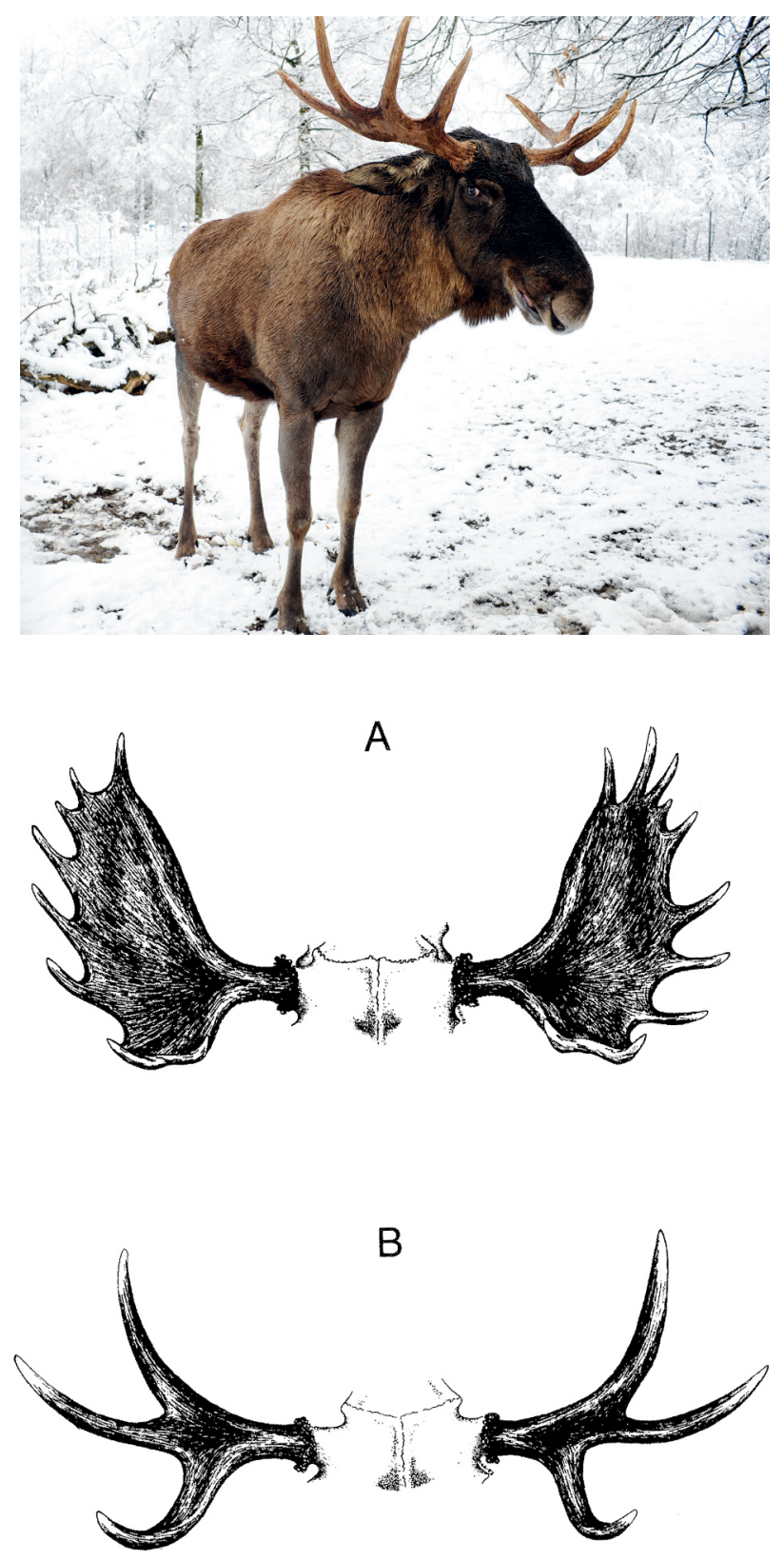

in March or even later in April or May. The growth of the following new antlers begins in April to July and is already finished after 2 to 2.5 months.

\section{2 | FOSSIL ELK}

The oldest fossil elks in Europe belong to the species Alces gallicus and are known from the Upper Villafranchian in Senèze (Haute-Loire, France) (Delpech and Guérin 1996 ; Kahlke 1994). They were smaller than recent elks. The antlers consisted of very long beams and relatively small palms. From the Middle Pleistocene the Alces latifrons is known in large parts of Eurasia. In France its remains were found f.e. in Achenheim (Bas-Rhin) and in Germany in Mosbach, Mauer and Süssenborn. Alces latifrons is the first elk species to migrate to North America via the Bering Strait. Alces latifrons could have a shoulder height of more than $2 \mathrm{~m}$. In contrast to the Alces gallicus the main beam of Alces latifrons was somewhat shorter, whereas the palms were larger (Kahlke 1994). The contemporary elk,

\section{FIGURE $3 c$}

Male elk with simple beam antlers (Photo and ๑ B. Schildger, Tierpark Bern). Élan mâle avec des bois simples (Photo and $\odot$ B. Schildger, Tierpark Bern).

\section{FIGURE 4}

Antlers of the elk. Palmate antlers (A) and simple beam antlers (B) (Nygrén 1986). Les bois d'élan. Bois palmés (A) et des bois simples (B) (Nygrén 1986).

Alces alces, originated at the end of the Late Pleistocene and is already known in the Eemian interglacial (Delpech and Guérin 1996; Kahlke 1990 ; Kahlke 1994). According to Kahlke (1994) Alces alces is rarely found in the Eemian. Also its fossil remains from the last glacial («Würm») are not frequent, although its range stretched from Eurasia to Europe (fig. 5).

Fossil remains of Alces alces are very rare in Upper Palaeolithic layers, too, (Serangeli 2006) which probably shows that elks were seldom hunted. Because of its antlers the elk, like the reindeer, would certainly have been a preferred hunting animal for the production of tools. The reason for the rarity of elk remains in general and in Upper Palaeolithic layers in particular could be that the elk, unlike other species of the Cervidae family - such as reindeer and red deer - lives as a loner. For the production of tools from elk antlers it is not necessary to kill the animal. The antlers which are dropped off every year can be used. 


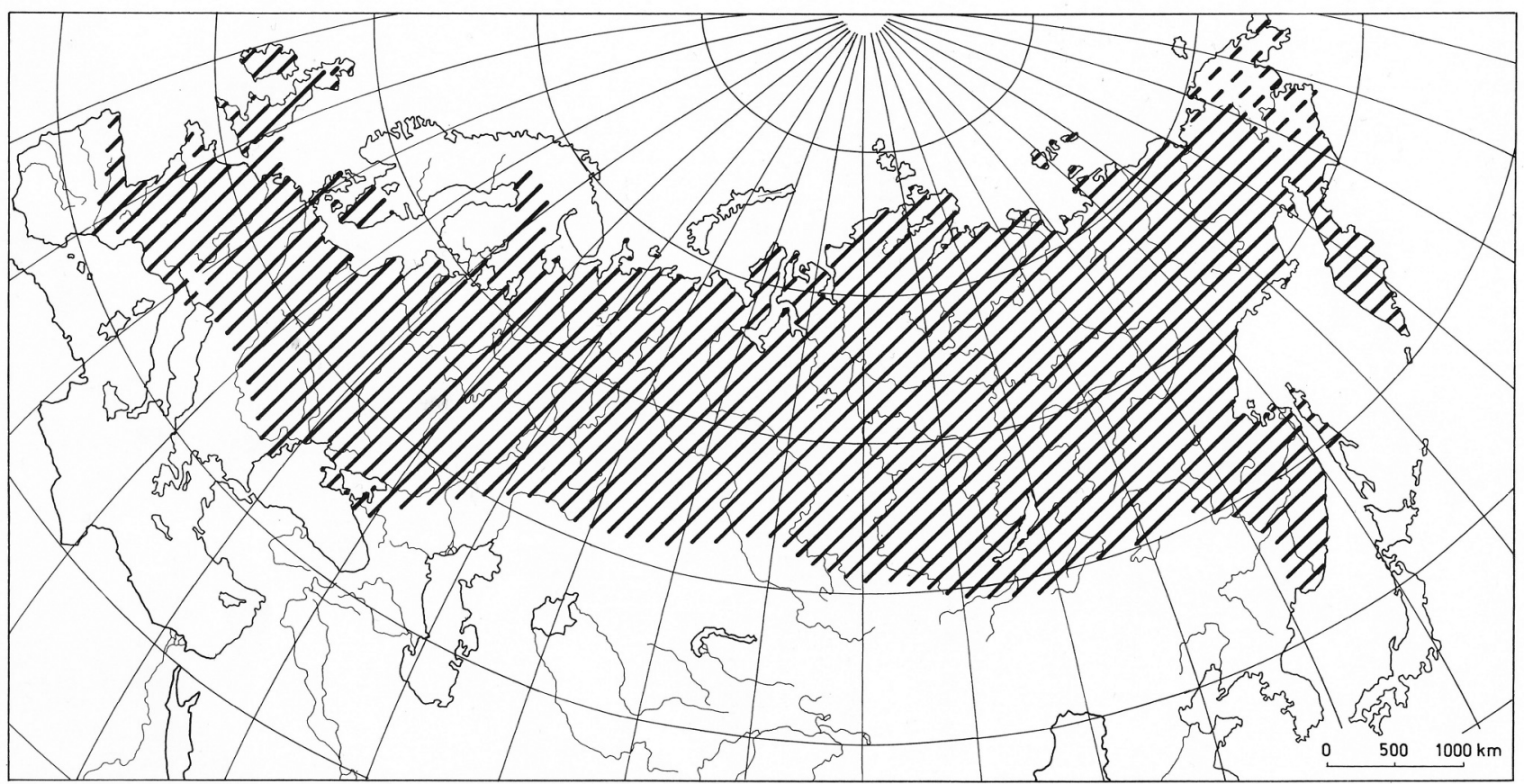

- FIGURE 5 -

Map of the maximum distribution of the elk in Eurasia in the last glacial period (MIS 5d - MIS 2) (Kahlke 1994).

\section{3 | THE ELK IN THE UPPER PALAEOLITHIC ART OF WESTERN EUROPE}

In 1967 Ucko and Rosenfeld wrote about the elk in the Upper Palaeolithic cave art: "The elk, which also lives in northern forests, is known to have lived in Europe during the Upper Palaeolithic. There are, however, no Palaeolithic parietal paintings, engravings or sculptures which can certainly be identified as representing the elk" (Ucko and Rosenfeld 1967 - p. 91). According to Crémadès (1993), however, the elk belongs to the rarely depicted animals in Upper Palaeolithic art. This corresponds well with the few fossil remains found in Upper Palaeolithic layers. For some representations it is also uncertain whether they really are elks. According to the investigations by Delpech (1983) the elk is only represented in the fauna of South West France from Magdalenian onwards. According to Serangeli (2006), however, in Gourdan (Haute-Garonne, France) it is already proven in the Solutrean. In northern Italy it is present only starting from the Epigravettian (Serangeli 2006). So far no fossil remains of elk are known from the Iberian Peninsula (email Pilar Fatas to the author ; Serangeli 2006).

Because of the very few elk representations known so far and also because of the uncertainty in certain cases as to whether they are really elks, it is not astonishing that there is no compilation of this animal species represented in Upper Palaeolithic art.

The aim of this article is to present an overview of the evident and potential elk representations from Upper Palaeolithic cave and portable art. With the exception of a potential representation from Altamira cave, the remaining few originate from cave and portable art in France (fig. 6). There are no known Upper Palaeolithic elk representations in other parts of Europe.
Carte de répartition maximale de l'élan durant la dernière période glaciaire (MIS 5d-MIS 2) (Kahlke 1994).

\section{1 | Cave Art}

\subsection{1 | Gargas (Hautes-Pyrénées, France)}

The Upper Palaeolithic cave art of Gargas was discovered by Félix Regnault in 1906 and has since been studied by various researchers. Gargas is best known for its very large number of negative hand stencils. There are also painted and especially numerous engraved depictions of animals (Barrière 1976 ; Breuil 1952 ; Breuil 1958 ; Foucher et al. 2007). The negative hand stencils from Gargas date to the Gravettian. A chronological classification of the engravings is rather difficult. According to Foucher and Rumeau (2007) some date stylistically into the Gravettian, others date rather into the Magdalenian. Four engraved elk depictions are known from Gargas.

\subsubsection{1 / Complete engraving on the Panneau du Grand Taureau}

This complete engraving is certainly one of the most evident representation of elk in cave art (fig.7). It is among other animal engravings on the Panneau du Grand Taureau (fig. 8). According to Barrière (1976) this engraving is $42 \mathrm{~cm}$ long and $28 \mathrm{~cm}$ high. The long head with the characteristic curvature in the area of the forehead-nose-line, the long legs, the two ears, the shoulder hump and the general morphology of the body clearly speak for a classification as elk. Breuil (1952) saw an elk in this representation due to the typical form of the head. No eye is shown and the tail is short. Due to the missing antlers it can be either a female or a male which has dropped off its antlers. Strangely enough, Crémadès (1997) only considers it to be a male animal after dropping off its antlers. 


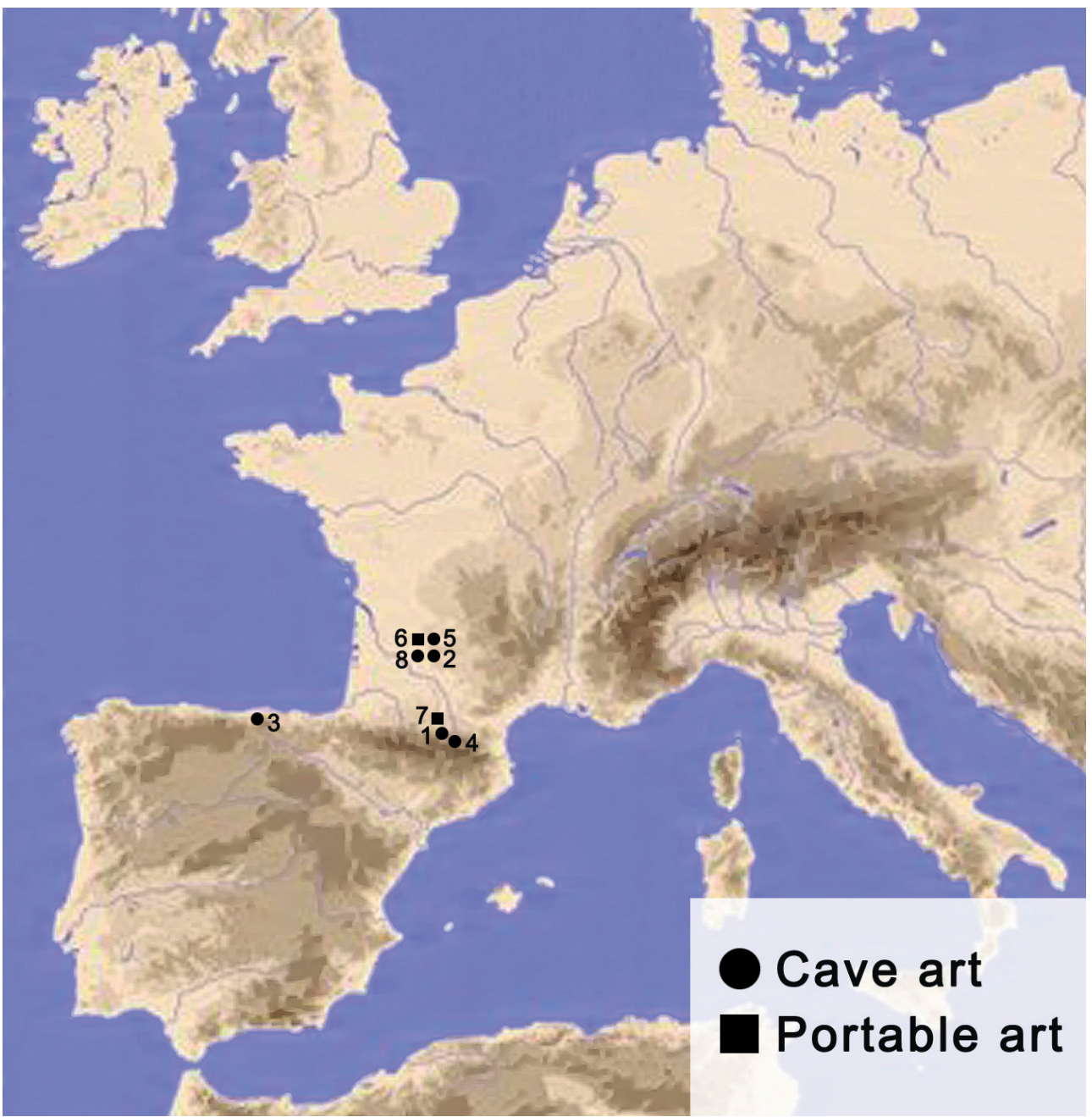

\section{FIGURE 6}

Distribution of sites with representations of elks in the Western European Upper Palaeolithic cave and portable art: 1 Gargas (F), 2 Roucadour (F), 3 Altamira (E), 4 Le Tuc d'Audoubert (F), 5 Les Combarelles I (F), 6 Unknown site near Les Eyzies-deTayac (F), 7 Gourdan (F), 8 Les Merveilles (F) (Drawing H.P. Steiner).

Répartition des sites avec des représentations d'élan dans l'art pariétal et l'art mobilier du Paléolithique de l'Europe occidentale. : 1 Gargas (F), 2 Roucadour (F), 3 Altamira (E), 4 Le Tuc d'Audoubert (F), 5 Les Combarelles I (F), 6 Site inconnu près des Eyzies-de-Tayac (F) 7 Gourdan (F), 8 Les Merveilles (F) (Dessin H.P. Steiner).

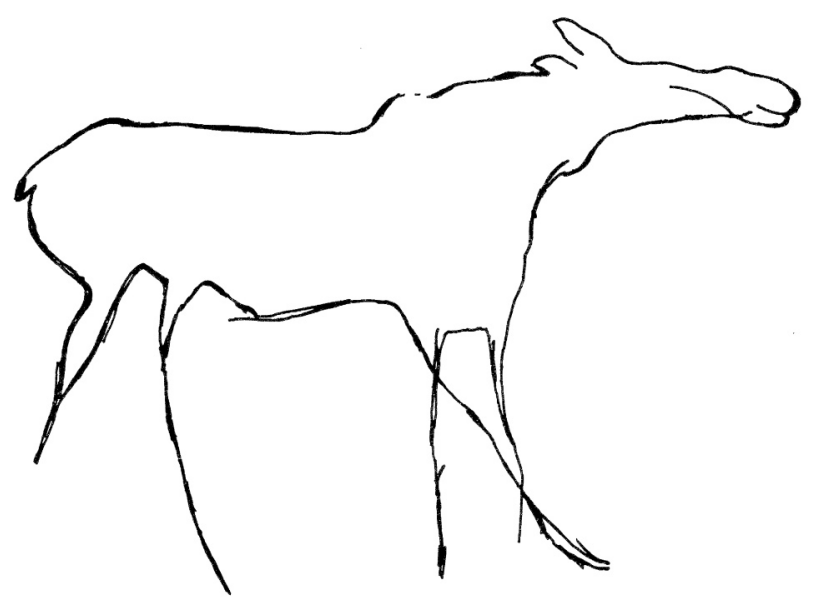

3.1.1.2 I Second complete engraving on the Panneau du Grand Taureau

On the same panneau (fig. 8) there is another complete engraving of an elk. According to Barrière (1976) the engraving is $68 \mathrm{~cm}$ long and $36 \mathrm{~cm}$ high. Like the previous one it has a large elongated head with the characteristic curvature, long legs and a shoulder hump (fig. 9a, b). In contrast to the previous representation only one ear and a longer tail are depicted. Also this elk representation shows no antlers and therefore it must remain open whether it is a female animal or a male after dropping off the antlers.

\section{FIGURE 7}

Gargas. Drawing of one of the complete representations of engraved elk figures (L. $42 \mathrm{~cm}$ ) of the Panneau du Grand Taureau (Barrière 1976).

Gargas. Dessin d'une représentation complète d'un élan gravé $(L .42 \mathrm{~cm})$ sur le Panneau du Grand Taureau (Barrière 1976).

\subsubsection{I Incomplete representation in the Sanctuaire des gravures}

On the drawings of the engravings in the Sanctuaire des gravures by Henri Breuil and by Claude Barrière there is an incomplete representation, which according to Breuil (1952) could represent either a hind or an elk due to the very long ears (fig. 10). The animal was drawn only with the head and the base of the chest and back line. In my opinion the elongated head with the curvature is typical of the elk. Similar to the two preceding complete elks from Gargas no eye and no antlers were represented. Thus the sex determination also remains open. According to Breuil (1952) these engravings date into the Gravettian. 


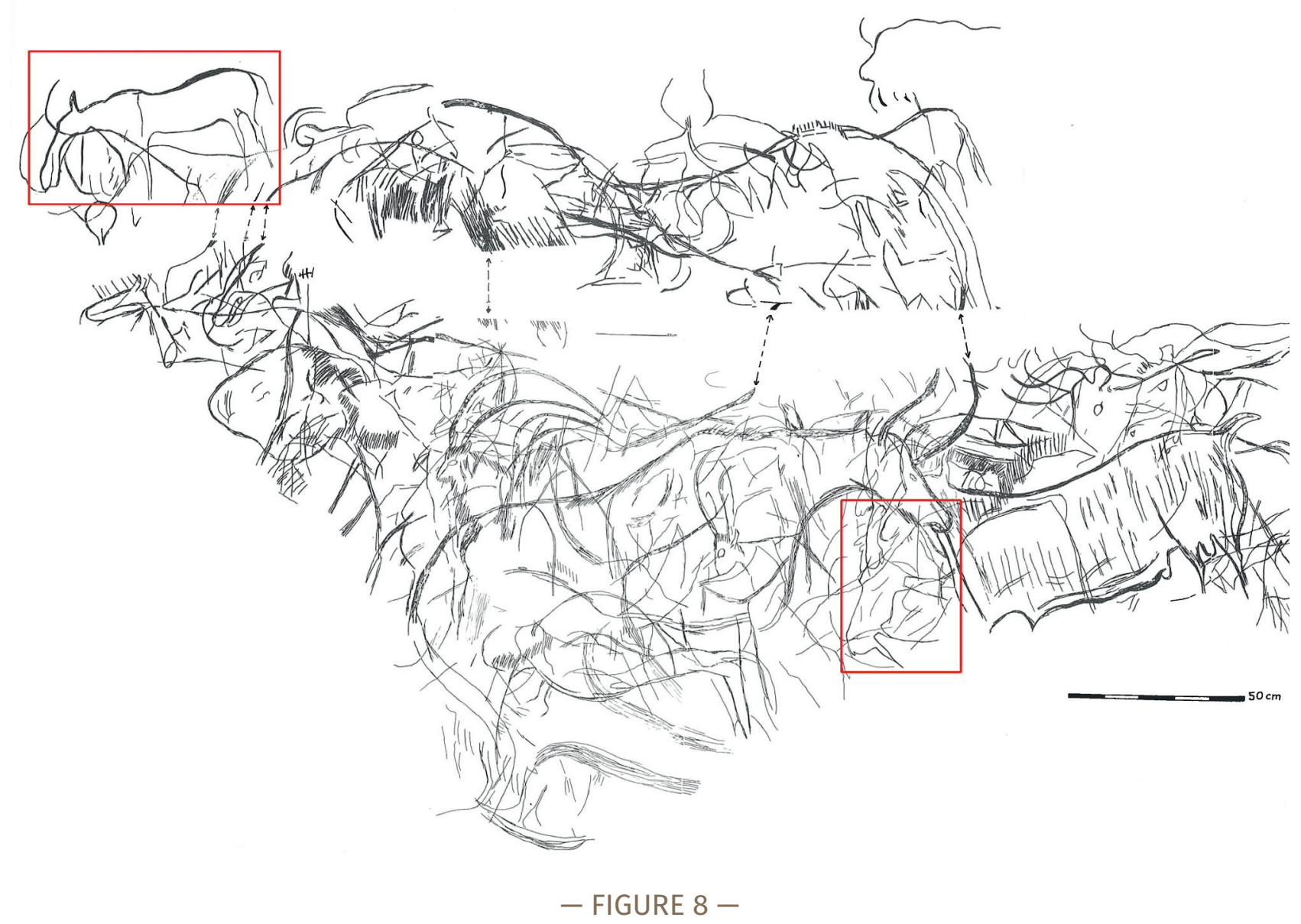

Gargas. Detail of the Panneau du Grand Taureau with the two complete representations of engraved elks (Barrière 1976, modified by H.P. Steiner).
Gargas. Détail du Panneau du Grand Taureau avec les deux figures gravées d'élans complets (Barrière 1976, modifié par H.P. Steiner).
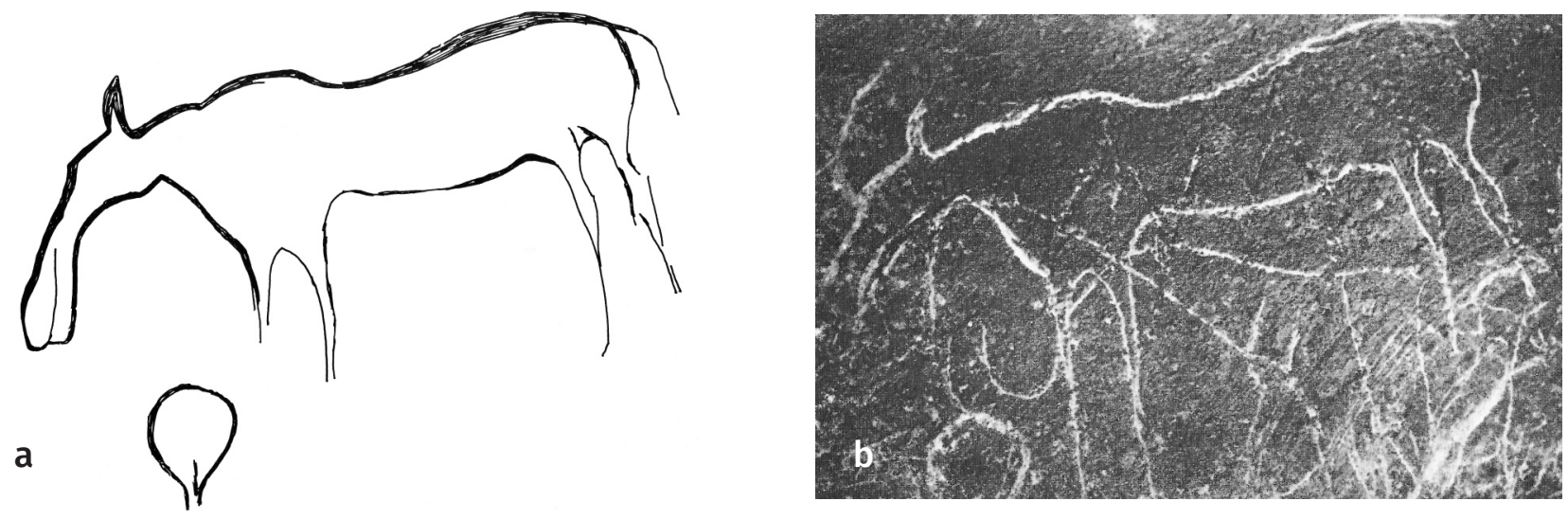

- FIGURE 9 -

Gargas. Second complete representation of an engraved elk figure of the Panneau du Grand Taureau (L. 68 cm); a : drawing (Barrière 1976); b : photo (Breuil 1952)
Gargas. Deuxième élan gravé complet du Panneau du Grand Taureau (L. $68 \mathrm{~cm})$; $a$ : dessin (Barrière 1976); b : photo (Breuil 1952).
3.1.1.4 / Second incomplete representation in the area of the Sanctuaire des gravures

Another incomplete representation of an animal can be found in the area of the Sanctuaire des gravures. It has great similarities with the previous one, as it was reproduced only with the head, the base of the belly and back line (fig. 11). The ears are also long, but the head has a less pronounced curvature than the already described three elk representations from the Gargas cave. Due to the great similarities, however, I think it is most likely an elk, too. 


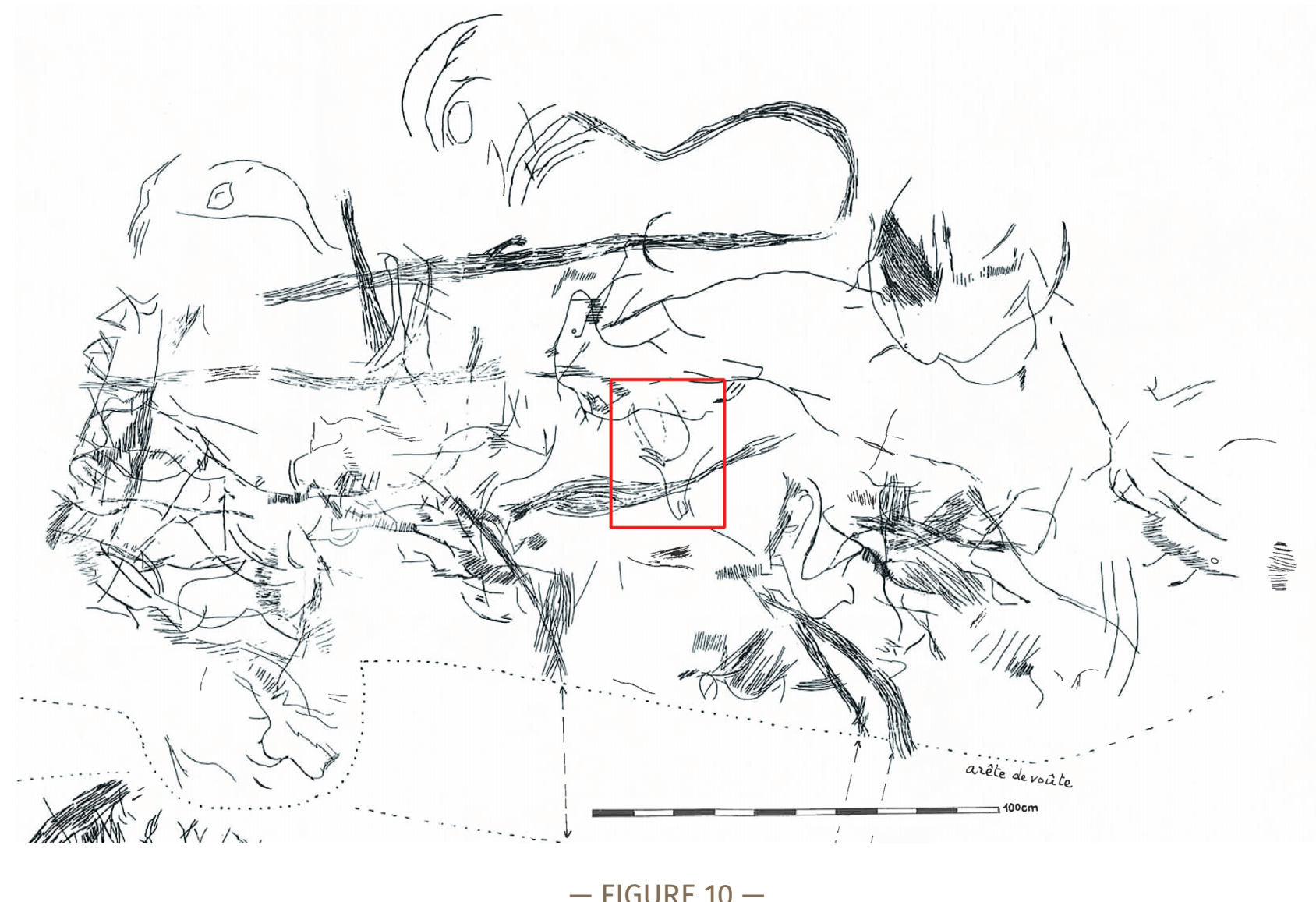

Gargas. Incomplete representation of an engraved elk in the area of the Sanctuaire des gravures (Barrière 1976, modiefied by H.P. Steiner).

Gargas. Représentation incomplète d'un élan gravé dans le secteur du Sanctuaire des gravures (Barrière 1976, modifiée par H.P. Steiner).

\subsection{2 | Roucadour (Lot, France)}

The cave art in Roucadour cave was discovered in 1962 by the two speleologists Pierre Taurisson and Jean-Paul Coussy. The first studies were undertaken by Abbé André Glory between 1964 and 1966. Due to a fatal accident in 1966 Glory could not continue his work or publish it himself (Lorblanchet 2018 ; Lorblanchet et al. 2009). Glory's drawings were finally published by Coussy (2005). In 2002 a new study of the representations began under the direction of Michel Lorblanchet and Jean-Marie Le Tensorer (Lorblanchet 2018 ; Lorblanchet et al. 2009). During these follow-up studies numerous new representations were discovered, including numerous giant deer and feline representations. The latter show great similarities with the cave lion images from the Chauvet cave (Ardèche, France). Due to stylistic comparisons with other caves the depictions from Roucadour are classified in an older phase of the Upper Palaeolithic, possibly in the Aurignacian and most probably in the Gravettian (Lorblanchet 2018). A monograph on the Roucadour cave is currently in preparation (oral communication by M. Lorblanchet).

The here present engraving (fig. 12) was discovered during Michel Lorblachet's new investigations and is located on Panneau X. According to Lorblanchet (2018) it is most likely an elk due to the large ears, the typically shaped muzzle and the beard below the lower jaw. I agree with this interpretation. The large ears Lorblanchet (2018) mentioned,

however, seem to me rather unbranched antlers. It could therefore be an elk in its second year of life. On the other hand it is also possible that it is an antler that is growing again after dropping off (fig. 13) (cf. 1.2 - The antlers). But it can be assumed that the short head rather belongs to a young animal in the second year of life.

\subsection{3 | Les Merveilles (Lot, France)}

The cave art of Les Merveilles was discovered in 1920 and investigated by different researchers. Michel Lorblanchet carried out the last investigations from 1968 to 1972 and finally from 1995 to 1997 . The cave consists of a single room. The representations are paintings of animals, negative hand stencils and signs, especially in the form of dots (Lorblanchet 2018). According to Lorblanchet (2018), the depictions from Les Merveilles cave, in particular the negative hand stencils, date to the Gravettian.

The here presented depiction of an animal, which is completely filled with black colour, is certainly an elk (fig. 14a, b). This identification is due to the long head with its characteristic shape, the beard and the long hind legs. The withers and one ear are also depicted. According to Lorblanchet (2018) this elk without antlers is more likely a female than a young male or a male after dropping off its antlers. The short tail is shown erected. Below the animal there are large red dots and black signs in the form of lines. 


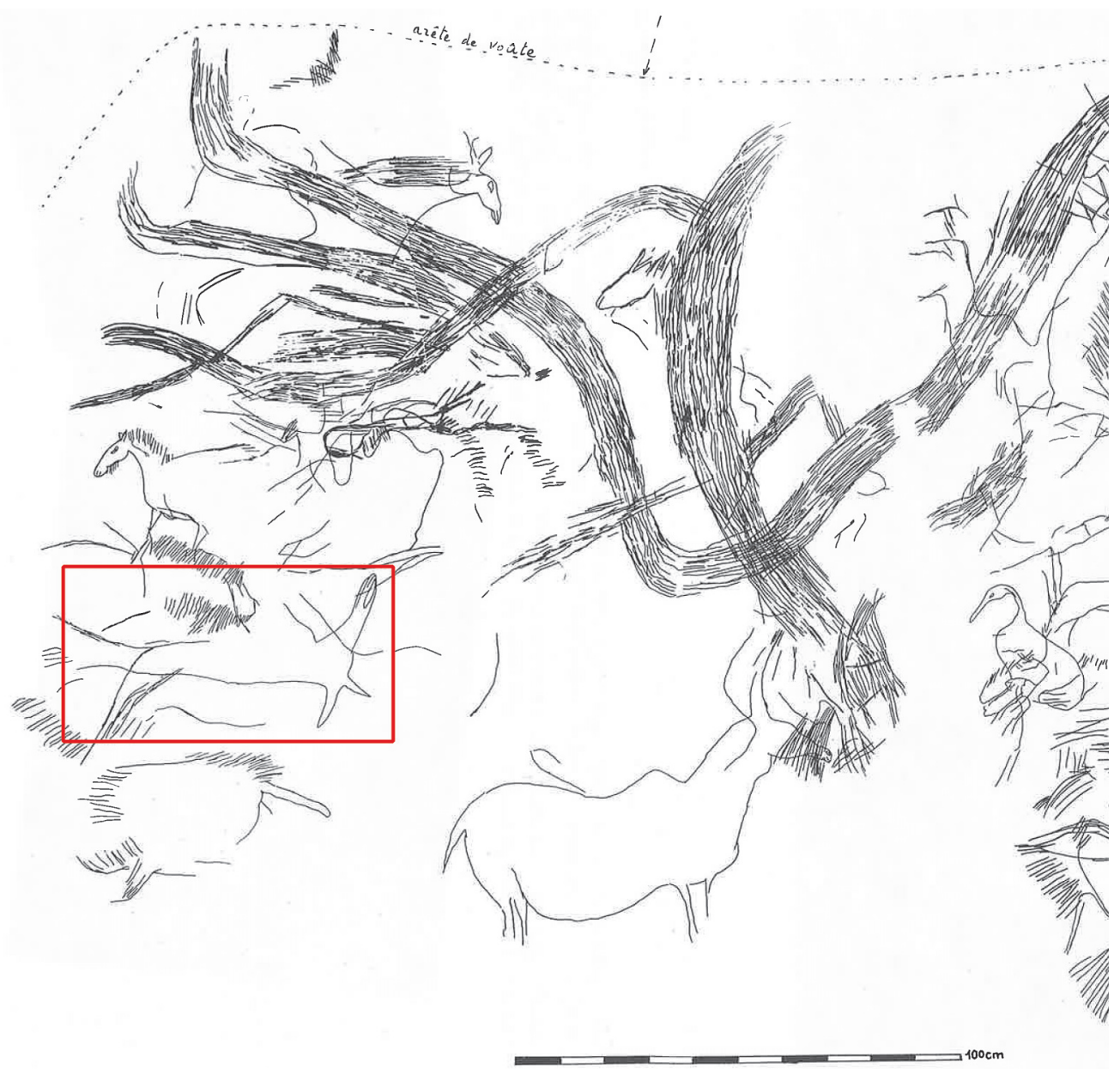

\section{FIGURE 11}

Gargas. Second incomplete representation of an engraved elk in the area of the Sanctuaire des gravures (Barrière 1976, modified by H.P. Steiner).

Gargas. Deuxième représentation incomplète d'un élan gravé dans le secteur du Sanctuaire des gravures (Barrière 1976, modifiée par H.P. Steiner).

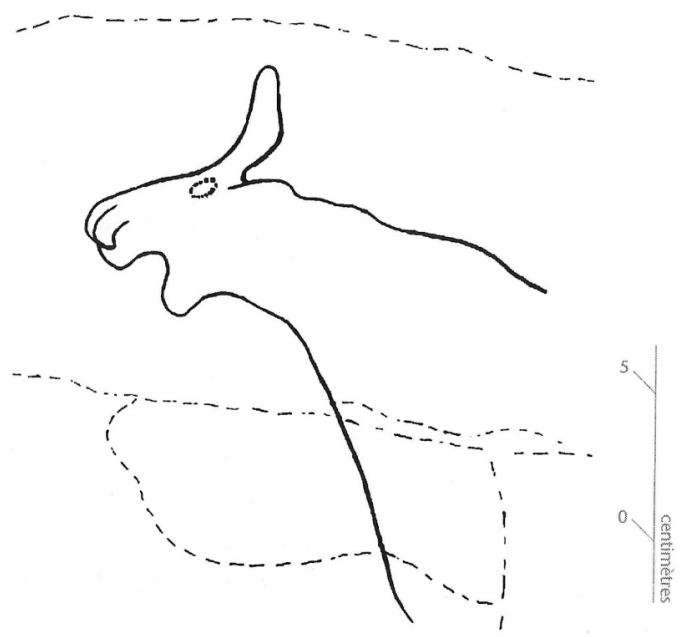

3.1.4 Altamira (Province of Cantabria, Spain)

The depictions in the Altamira cave were discovered as early as 1879, but were not recognised as depictions from the Upper Palaeolithic until 1902.

A red painting was interpreted by Breuil and Obermaier (1935) as an elk (fig. 15a, b). Especially the right antler beam clearly shows the characteristic palms of an elk in Henri Breuil's drawing (fig. 15a). In Breuil's drawing, however, no prominent shoulder hump is visible and the legs are not very long as it is typical for elk. There are several small red dots on the body of the animal which can be seen on

\section{FIGURE 12}

Roucadour. Drawing of the engraved elk figure (Lorblanchet 2018).

Roucadour. Dessin de la figure gravée d'élan (Lorblanchet 2018).

Breuil's drawing and on the photo. According to Jordá Cerdá (1972 - p. 427-428) it is an elk, too, because of the characteristic antlers: "Un alce en rojo dibujado con anchas bandas, difuminadas, de estilo muy primitivo. Los cuernos son típicos y el cuerpo se conserva imperfectamente en su parte posterior [...]"1. Nowadays this figure is in a bad state of conservation. Some parts are

[1] An elk drawn in red with wide blurred bands, of very primitive style. The antlers are typical and the body is imperfectly preserved at the back [...] (Translation by Ingmar M. Braun) 


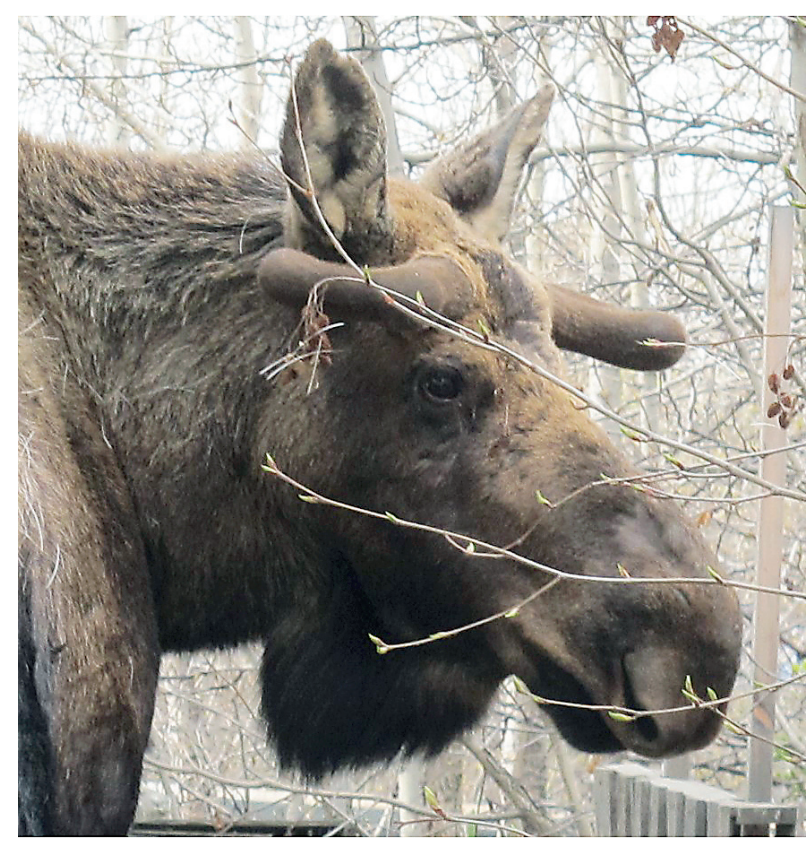

partially covered with calcite and there are traces of graffiti made with black smoke after the discovery (fig. 15b). The figure is located in the Great Ceiling near the ground which does not favour its correct study (email Pilar Fatas to the author). The question remains unanswered whether it is an elk or perhaps another kind of the species of Cervidae (Mallo Viesca 1976/77 ; email Pilar Fatas to the author).

\subsection{5 | Le Tuc d'Audoubert (Ariège, France)}

The cave Le Tuc d'Audoubert belongs together with the caves Les Trois-Frères and Enlène to the so-called «Cavernes du Volp». In 1912 the three young people Max, Jacques and Louis Bégouën - the three sons of the famous prehistorian and Count Henri Bégouën discovered the first cave art while exploring the cave and, in the same year, the famous «bisons d'argile» at the end of the cave (Bégouën and Breuil 1958 ; Bégouën et al. 2009). The two engravings presented here are located at the entrance to the Chatière, which leads to the Bisons d'Argile (fig. $16 ; 17 a, b$ and 18). Bégouën and Breuil saw in these two representations "[...] animaux fantastiques, mi-Félins, miTaureaux [...]" (Bégouën and Breuil 1958 - p. 89), probably the «guardians» of the Bisons d'Argile. Robert Bégouën, the grandson of Henri Bégouën, described the two figures as follows: "La forme animale s'impose: le premier a une tête au mufle proéminent rappelant celle de l'Elan, une corne unique et une large oreille, le corps évoquant celui du kangourou, le tout sans aucun indice zoologique déterminable. La représentation du second animal est réduit à sa tête, sans corne, et à la partie supérieure de l'encolure. Son graphisme procède cependant du même concept et son "air de famille" avec son voisin est flagrant" (Bégouën 1993 - p. 208). Almost 20 years later Robert Bégouën writes in the monograph of the cave Le Tuc d'Audoubert about the upper figure: "Aucune référence zoologique claire ne vient à l'esprit; il ne s'agit pas plus d'une créature composite, mais bel et bien d'un animal irréel, pure création de l'imaginaire magdalénien" (Bégouën 2009 - p. 226). I do not see any fantasy or mixed creatures in these two representations. In my opinion the

\section{FIGURE 13}

Male elk in Alaska whose antlers are growing again after dropping off (Photo I. M. Braun).

En Alaska, élan mâle dont les bois repoussent après la chute (Photo I. M. Braun).

upper representation in particular could best represent an elk, especially due to the shape of the head typical of an elk and the clear shoulder hump. In the horn, already described by Bégouen (1993), I see the antlers of the first development step, as it is characteristic for male elks in the second year of life (see chapter 1.2 - The antlers). As with the representation from the Roucadour cave (see 3.1.2) it is also possible that it is an antler growing again after the dropping off (fig. 13). Also here the relatively short head could rather indicate a young animal.

\subsection{6 | Les Combarelles I (Dordogne, France)}

Located in Les Eyzies, Les Combarelles I cave is best known for its numerous engravings discovered in 1901. The depictions are dated to the Magdalenian. A first monograph on the cave was written by L. Capitan, H. Breuil and D. Peyrony (Capitan et al. 1924). The following figure is not mentioned in the second monograph by C. Barrière in 1997. In the engraving from Les Combarelles I Capitan et al. (1924) see the head of a cave bear (fig. 19). In my opinion, however, it is more likely an elk than a cave bear. In my opinion this interpretation is supported by the shape of the head and the muzzle, the nostril pointing forward and the large ears. Those are characteristics which actually do not correspond to a cave bear. The peculiar line running behind the ears shows a strong hump, which could also correspond to the hump of an elk.

\section{2 | Portable art}

\subsection{1 | Unknown site near Les Eyzies (Dordogne, France)}

From an unknown site near Les Eyzies-de-Tayac a fragmented slate plate is known with an engraved detailed head and the base of the back of an animal (fig. 20). The slate plate was found in June 1984 by a boy allegedly in the Abri Lartet in Les Eyzies-de-Tayac (Dordogne, France). However, Gaussen and Merlaud (1987) ruled out the possibility that this find came from the Abri Lartet, as only remains of the Aurignacian and Gravettian are found there and do not correspond to the style of the depiction. The 

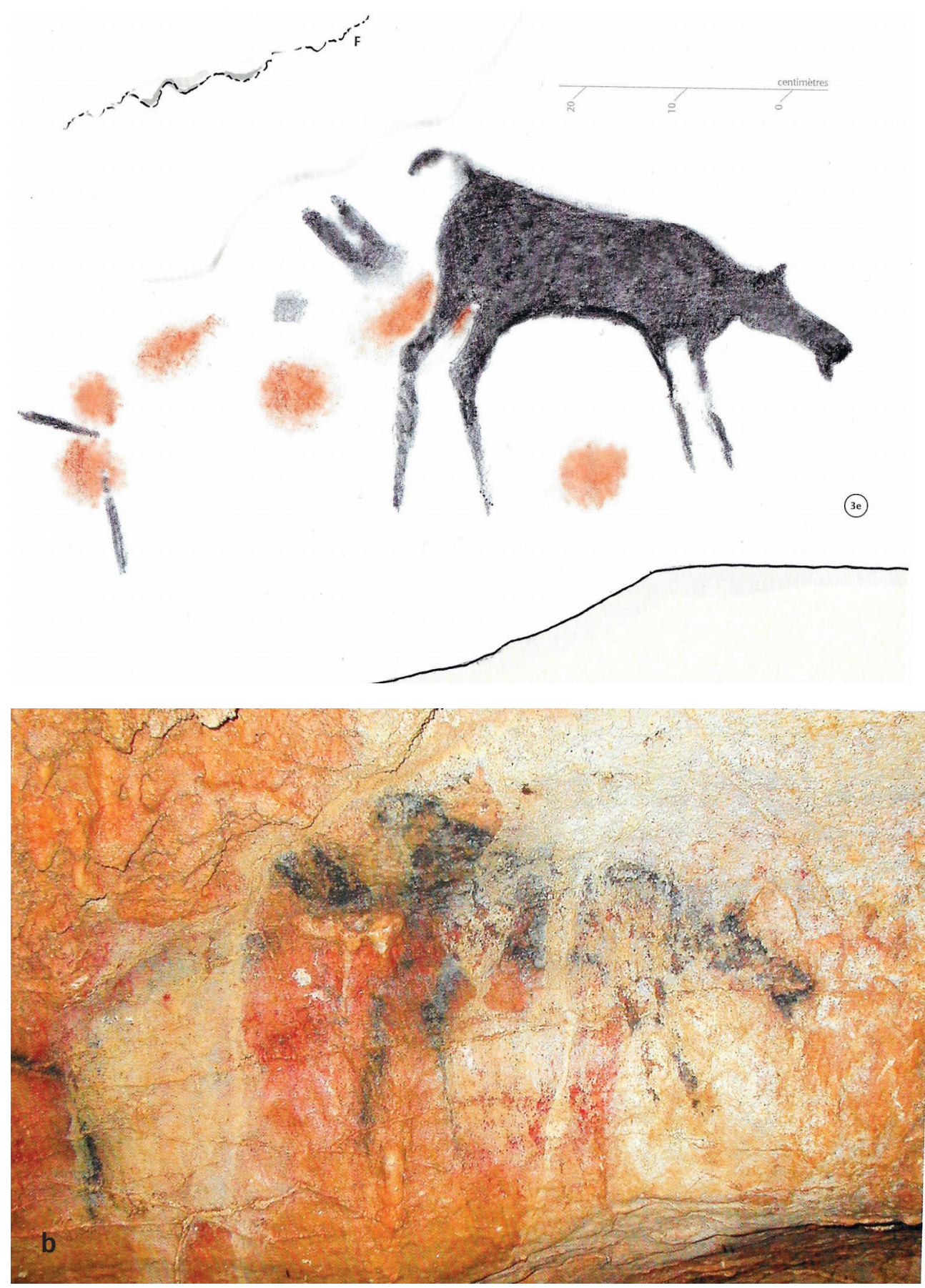

\section{FIGURE 14}

Les Merveilles. Black painted elk figure (Lorblanchet 2018); a : drawing ; $b$ : photo.

Les Merveilles. Elan peint en noir (Lorblanchet 2018); a : dessin ; b: photo.

two authors rather assume that the slate plate comes from the nearby Grotte d'Abzac with findings of the Upper Magdalenian.

Due to the characteristic shape of the head and the recognizable hump on the back this figure can only be an elk. According to the finder of the engraved slate plate it is a hind (Gaussen and Merlaud 1987). The two researchers of the object finally assume that it is a female elk because the antlers are absent (Gaussen and Merlaud 1987). They rather exclude an interpretation as a male animal with antlers thrown off. In my opinion an assignment to the elk is certain, but the sex determination must remain open. It is quite probable that the find comes from the Grotte d'Abzac, as the elk in South West France appeared in the fauna in the Magdalenian (Delpech 1983).

\subsection{2 | Gourdan (Haute-Garonne, France)}

The Gourdan Cave - also known as the Eléphant Cave - is located in the municipality of Gourdan-Polignan, above the confluence of the Garonne River and the Neste River. The cave was recognised as a prehistoric site in 1870 and excavated by Edouard Piette between 1871 and 1875. In the Great Hall objects from the Aurignacian, Middle and Upper Magdalenian and Late Palaeolithic (Azilian) periods were discovered. In the Middle and Upper Magdalenian layers numerous important portable art objects were found. Later excavations were carried out between 1985 and 1992 under the direction of Jacques Virmont. The first Upper Palaeolithic cave engravings were discovered in 1989 (Piette 1907 ; Schwab 2008). 

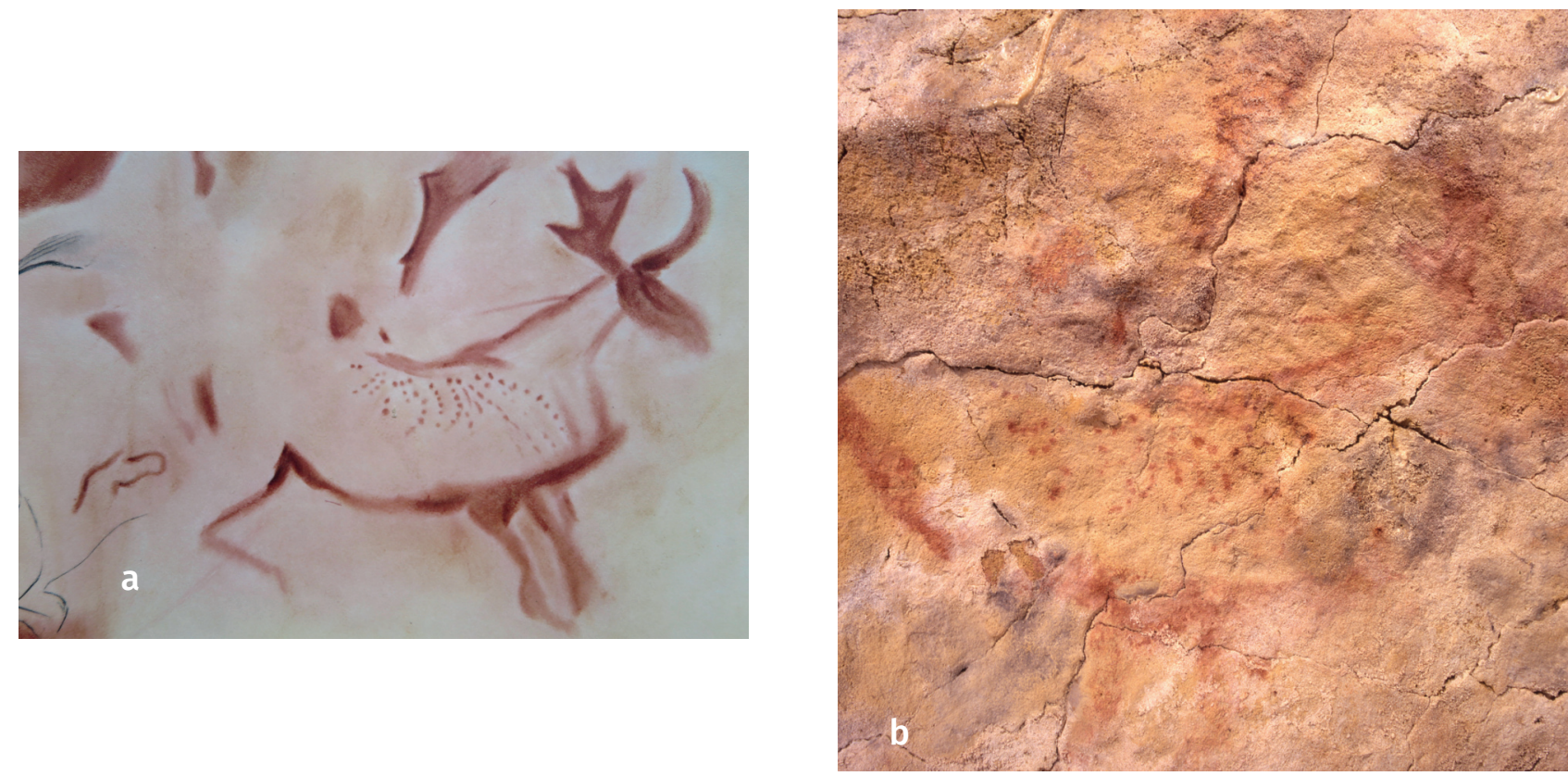

\section{- FIGURE $15-$}

Altamira. Red painted elk figure (L. $160 \mathrm{~cm})$ according to H. Breuil and H. Obermaier; a: drawing by H. Breuil (Breuil and Obermaier 1935); b: photo (৫ Museo de Altamira, Photo: P. Saura).
Altamira. Figure d'élan peinte en rouge $(L .160 \mathrm{~cm})$ d'après $H$. Breuil et H. Obermaier ; $a$ : dessin par H. Breuil (Breuil et Obermaier 1935); $b$ : photo (๑ Museo de Altamira, Photo: P. Saura).

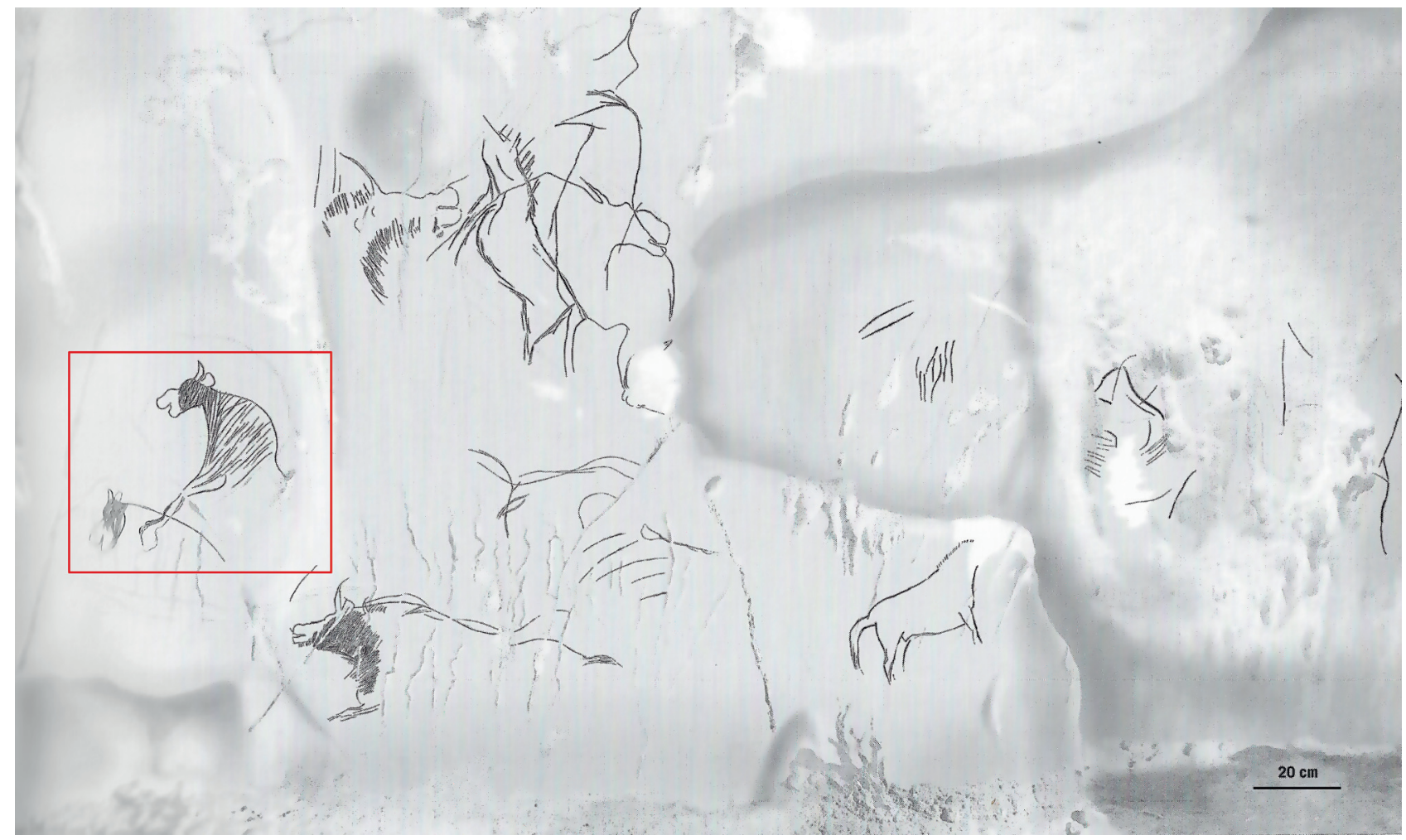

\section{- FIGURE 16 -}

Le Tuc d'Audoubert. Drawing of the ceiling and the wall of the Passage des Monstres (c) Drawing J. Clottes, F. Faist, C.Fritz and G. Tosello, in: Bégouën et al. 2009, modiefied by H.P. Steiner).
Le Tuc d'Audoubert. Relevé de la voûte et de la paroi du Passage des Monstres. (๔ Relevé J. Clottes, F. Faist, C.Fritz and G. Tosello, in: Bégouën et al. 2009, modifié par H.P. Steiner). 

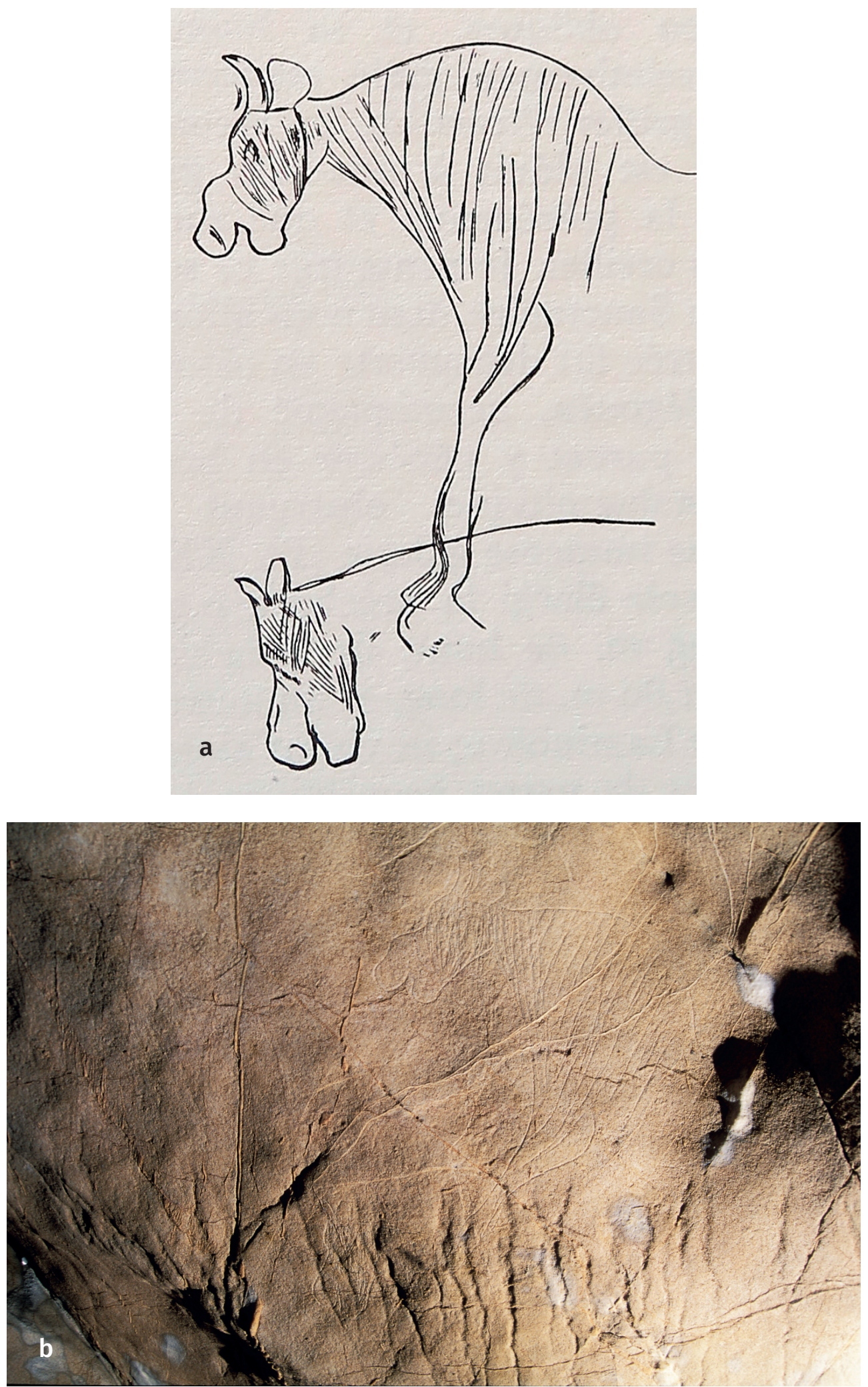

\section{FIGURE 17}

Le Tuc d'Audoubert. Detail of the two engraved potential elk figures; $a$ : drawing (Bégouën and Breuil 1958) ; b : photo (O R. Bégouën).

Le Tuc d'Audoubert. Détail des deux figures d'élan potentiel gravées: a: dessin (Bégouën et Breuil 1958); $b$ : photo (@ R. Bégouën).

Among the Magdalenian engravings on antlers there are two depictions that can be interpreted as elks. They are described as follows.

\subsubsection{I Engraving of an animal from the front on antlers}

The object presented here is an antler fragment showing an animal from the front (fig. 21a, b). According to Chollot $(1964,105)$ it is a "ciseau-poussoir" of $12 \mathrm{~cm}$ length and $1 \mathrm{~cm}$ width. Piette (1907) saw a reindeer in the animal representation. In the monograph on the Font-de-Gaume cave by Louis Capitan, Henri Breuil and Denis Peyrony this engraving is, however, referred to as an elk (Capitan et al. 1910). Also Chollot regards it as "Un élan remarquablement stylisé vu de face" (Chollot 1964 - p. 105). In my opinion especially the characteristic muzzle of an elk and the two antler beams, which remind of palmate antlers, favour an elk. 

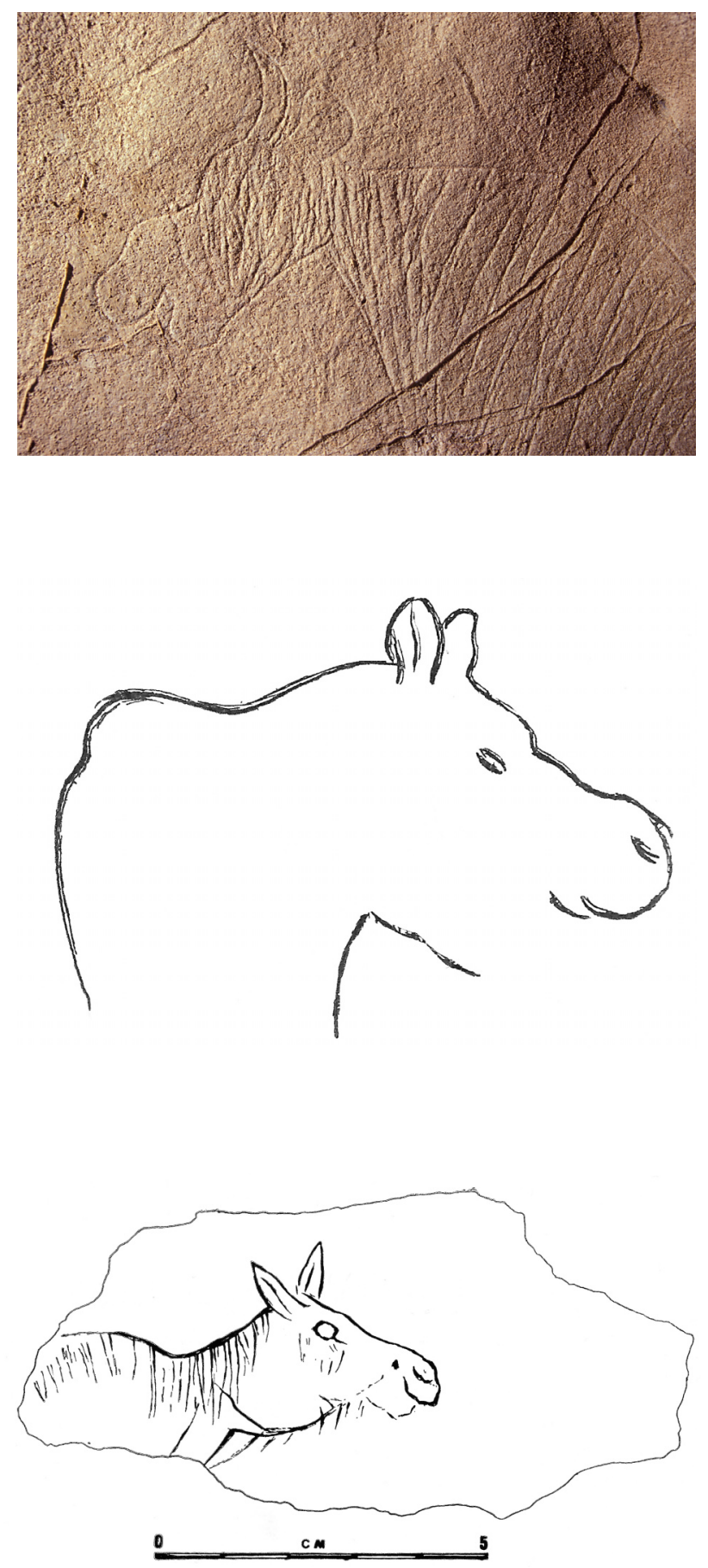

\subsubsection{2 - Engraving on antlers}

According to Piette (1907) the second object from Gourdan (fig. 22a to 22c), also made on antlers, is a "brunissoir". Apart from non-figurative engraved lines, which Piette called vshaped signs, only a back line with a hump and a large antler with at least four ends (Piette 1907, Pl. XXX:12) can be seen on the object. Interestingly, Henri Breuil's drawing shows an elongated oval ear which is the antler base in Piette's publication. According to Capitan et al. (1910) it is an incomplete engraving. I rather regard it as an elk that is about to eat water plants in the water. Heptner and Nasimowitsch (1967 - p. 125) write about an elk searching for food in the water: "Wasserpflanzen holen die Elche herauf, indem sie mit dem Kopf 20 bis 60 Sekunden untertauchen [...]. Im flachen Wasser ziehen sie es vor, den

\section{FIGURE 18}

Le Tuc d'Audoubert. Detail of the head of the upper figure (@ Photo R. Bégouën). Le Tuc d'Audoubert. Détail de la tête de la figure supérieure (৫ Photo R. Bégouën).

\section{FIGURE 19}

Les Combarelles I. Drawing of the potential engraved elk figure (Capitan et al. 1924).

Les Combarelles I. Dessin de la figure gravée d'un élan potentiel (Capitan et al. 1924).

\section{FIGURE 20}

Unknown site near Les Eyzies-de-Tayac. Drawing of an engraved elk on a slate plaquette (Gaussen and Merlaud 1987).

Site inconnu près des Eyzies-de-Tayac. Dessin d'un élan gravé sur une plaquette de schiste (Gaussen et Merlaud 1987)

Kopf nur bis zu den Ohren ins Wasser zu bringen [... $]^{\prime 2}$. In my opinion this description of food intake in the water fits very well with the representation from Gourdan. In my opinion the Upper Palaeolithic artist might have considered the longitudinal edge of the lissoir as the waterline and this explains why the animal was incompletely depicted.

[2] Elks bring up water plants by submerging with their heads for 20 to 60 seconds [... In shallow water they prefer to hold the head only up to the ears into the water [...] (Translation by Ingmar M. Braun) 

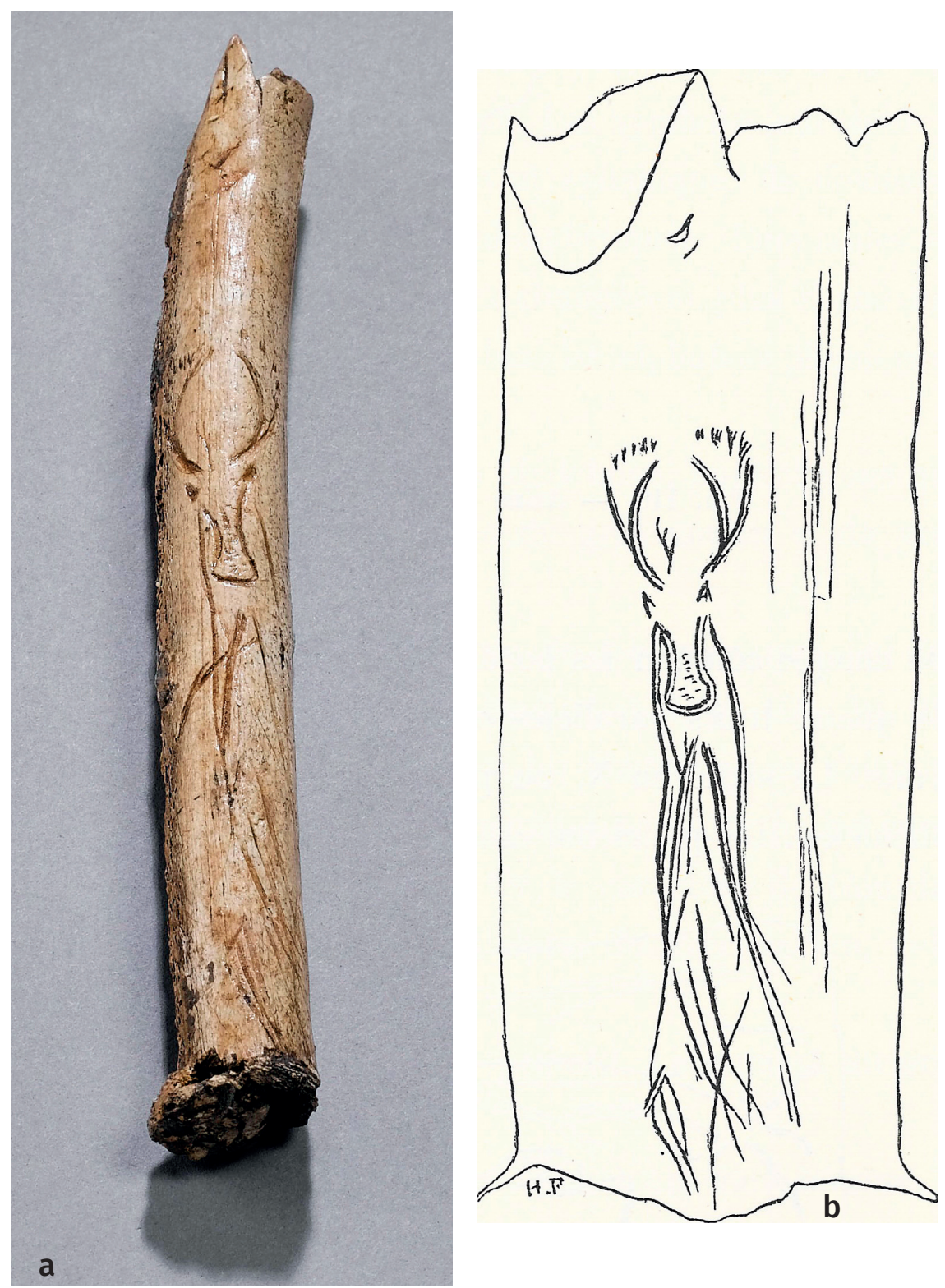

\section{FIGURE 21}

Gourdan. Potential engraved elk from the front on antlers of the reindeer $(\mathrm{L} .12 \mathrm{~cm})$; a: photo (Photo (c) RMN-Grand Palais (musée d'Archéologie nationale) / T. Le Mage); b: drawing (Piette 1907).

Gourdan. Elan potentiel gravé de face sur bois de renne (L. $12 \mathrm{~cm})$; a : photo (Photo 0 RMN-Grand Palais (musée d'Archéologie nationale) / T. Le Mage); $b$ : dessin (Piette 1907).
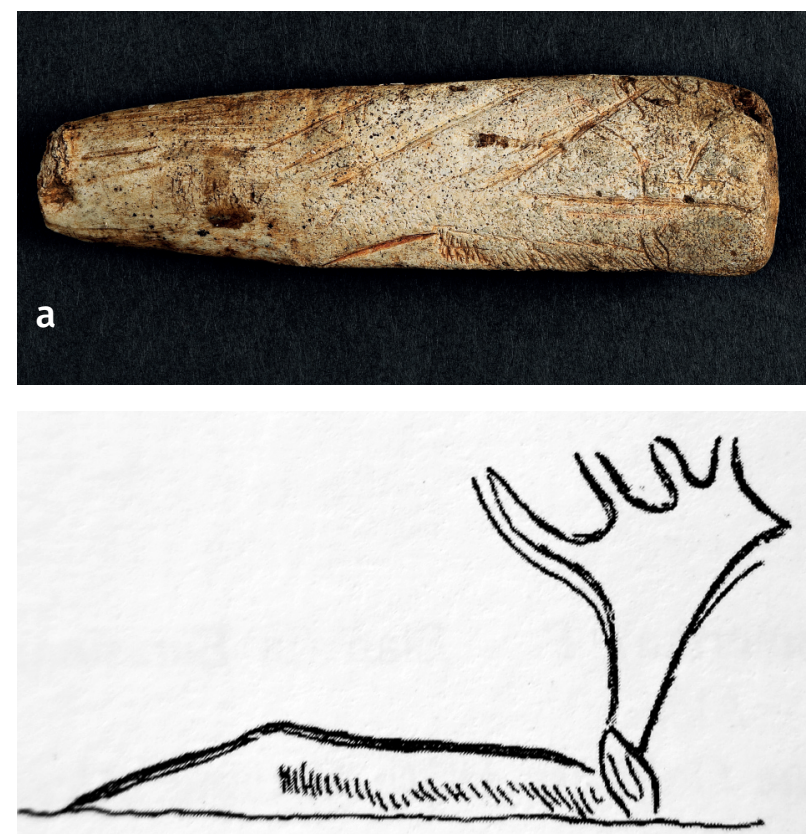

C

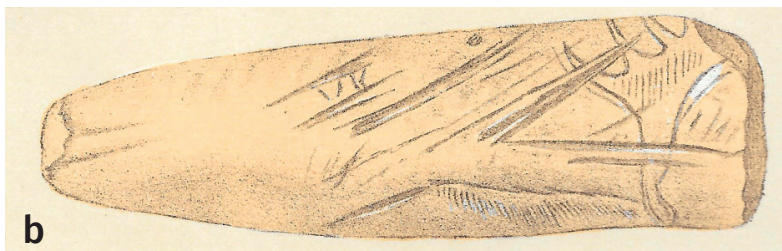

\section{FIGURE 22}

Gourdan. Potential engraved elk on antlers of the reindeer $(L .8,5 \mathrm{~cm})$; a : photo (৫ MAN / V. Gô); b : drawing (Piette 1907); c: drawing by H. Breuil (Capitan et al. 1910).

Gourdan. Élan potentiel gravé sur bois de renne (L. 8,5 cm); a: photo (O MAN / V. Gô); $b$ : dessin (Piette 1907); c : dessin par H. Breuil (Capitan et al. 1910). 


\section{CONCLUSIONS}

With their typical form of head and the often palmate antlers of the males elks can be distinguished well from other Cervidae. In spite of their large geographical distribution in Eurasia, representations of elk are very rare in Upper Palaeolithic cave and portable art. This corresponds well to the rarity of its fossil remains from the last glacial period. The rare occurrence of elk remains in Upper Palaeolithic layers of Europe also shows that they were rarely hunted or could not be hunted due to their rarity. However, the few so far known depictions of elks in Upper Palaeolithic art of Western Europe are proof that this animal was consciously perceived by the people of that time.

\section{ACKNOWLEDGEMENTS}

I want to thank all those who gave me photos of contemporary elks and of figures of elks in cave and portable art. Furthermore I would like to thank H.P. Steiner for making the map with the sites of the representations of elks in cave and portable art and for the modifications of some figures. I am grateful to Dr. D. Ambros and Dr. J. Hansen for the cross-reading of the article and finally $C$. Boussat and her team of Paleo for the redaction of this article.

\section{REFERENCES}

BARRIÈRE C. 1976 - L'art pariétal de Gargas. Oxford : BAR Supplementary Series 14, 2 volumes, ill.

BARRIĖRE C. 1997 - L'art pariétal des grottes des Combarelles. Angoulême : Paleo Hors série, 609 p., ill.

BÉGOUËN H., BREUIL H. 1958 - Les cavernes du Volp : TroisFrères, Tuc d'Audoubert à Montesquieu-Avantès (Ariège). Paris : Arts \& Métiers Graphiques, 123 p., ill.

BÉGOUËN R. 1993 - III - Les animaux irréels. In: Aujoulat N. et al., L'art pariétal paléolithique. Techniques et méthodes d'étude. Paris : Editions du Comité des Travaux Historiques et Scientifiques, p. 207-210, ill.

BÉGOUËN R., FRITZ C., TOSELLO G., CLOTTES J., PASTOORS A., FAIST F. 2009 - Le sanctuaire secret des bisons. Il y a 14000 ans, dans la caverne du Tuc d'Audoubert ... Paris : Somogy, 415 p., ill.

BREUIL H. 1952 - Quatre cents siècles d'art pariétal. Montignac (Dordogne) : Centre d'études et de documentation préhistoriques, 413 p., ill.

BREUIL H. 1958 - La décoration pariétale préhistorique de la grotte de Gargas. Bulletin de la Société d'Histoire Naturelle de Toulouse, 93, p. 391-409, ill.

BREUIL H., OBERMAIER H. 1935 - The cave of Altamira at Santillana del Mar, Spain. Madrid : Tipografia de Archivos, 223 p., ill.

CAPITAN L., BREUIL H., PEYRONY D. 1910 - La caverne de Font-de-Gaume aux Eyzies (Dordogne). Monaco : Impr. A. Chêne, 271 p., ill.
CAPITAN L., BREUIL H., PEYRONY D. 1924 - Les Combarelles aux Eyzies (Dordogne). Paris : Masson et Cie, 192 p., ill.

CHOLLOT M. 1964 - Musée des Antiquités Nationales Collection Piette - Art mobilier préhistorique. Paris: Editions des Musées Nationaux, 479 p., ill.

COUSSY J.-P. 2005 - Roucadour - L'art initial gravé. Cahors : Imprimerie France Quercy, ill.

CRÉMADÈS M. 1993 - III - Les cervidés. In: Aujoulat N. et al., L'art pariétal paléolithique. Techniques et méthodes d'étude. Paris : Editions du Comité des Travaux Historiques et Scientifiques, p. 137-150, ill.

CRÉMADĖS M. 1997 - La représentation des variations saisonnières dans l'art paléolithique. L'Anthropologie (Paris), T. 101/1, p. 36-82, ill.

DELPECH F. 1983 - Les faunes du Paléolithique supérieur dans le Sud-Ouest de la France. Paris : Centre national de la recherche scientifique, 453 p., ill.

DELPECH F., GUÉRIN C. 1996 - IV. Famille des Cervidae. In: Guérin, C., Patou-Mathis M. (Eds.), Les grands mammifères plio-pleistocènes d'Europe. Paris, Milan, Barcelone : Masson, p. 47-62.

FOUCHER P., SAN JUAN-FOUCHER C., RUMEAU Y. 2007 - La grotte de Gargas - Un siècle de découvertes. 125 p., ill.

FOUCHER P., RUMEAU Y. 2007 - Les galeries ornées de Gargas. In: Foucher P., San Juan-Foucher C., Rumeau Y., La grotte de Gargas - Un siècle de découvertes. p. 61-86.

GAUSSEN J., MERLAUD B. 1987 - Une identification difficile. Préhistoire Ariégeoise, 42, p. 165-169, ill.

HEPTNER W.G., NASIMOWITSCH A.A. 1967 - Der Elch (Alces alces L.). Wittenberg Lutherstadt: Die neue BrehmBücherei, 231 p., ill.

JORDA CERDA F. 1972 - Las superposiciones en el gran techo de Altamira. In: Almagro Basch M., García Guinea, Santander Symposium. Santander - Madrid : Union internationale des sciences préhistoriques et protohistorique, p. 423-449.

KAHLKE H.D. 1990 - On the Evolution, Distribution and Taxonomy of Fossil Elk/Moose. Quartärpaläontologie, 8, p. 83-106, ill.

KAHLKE R.-D. 1994 - Die Entstehungs-, Entwicklungs- und Verbreitungsgeschichte des oberpleistozänen Mammuthus-Coelodonta-Faunenkomplexes in Eurasien (Grosssäuger). Frankfurt a. M. : Abhandlungen der Senkenbergischen Naturforschenden Gesellschaft 546, 115 p., ill.

LORBLANCHET M. 2018 - Art pariétal - Grottes ornées du Quercy. Edition augmentée. Rodez : Rouergue, 472 p., ill.

LORBLANCHET M., DELLUC B., DELLUC G., LE TENSORER J.-M., BARIVIERA G., BOURNAZEL J. 2009 - Roucadour quarante ans plus tard. Préhistoire du Sud-Ouest, 17/1, p. 5-94, ill.

MALLO VIESCA M. 1976/77 - Las representaciones prehistoricas del alce en España - Un nuevo caso sujeto a discusión. Sautuola, II, p. 59-66, ill. 
NYGRÉN K. 1986 - Alces alces (Linnaeus, 1758) - Elch. In: Niethammer J., Krapp F. (Eds.), Handbuch der Säugetiere Europas. Band 2/II Paarhufer. Wiesbaden : Aula, p. 173-197.

PIETTE E. 1907 - L'art pendant l'âge du Renne. Paris : Masson et $\mathrm{Cie}^{\mathrm{e}}, 112$ p., ill.

REICHHOLF J. 1982 - Säugetiere. Die farbigen Naturführer. München : Mosaik, 287 p., ill.

SCHWAB C. 2008 - La Collection Piette. Paris : Réunion des musées nationaux, 127 p., ill.
SERANGELI J. 2006 - Verbreitung der grossen Jagdfauna in Mittel- und Westeuropa im oberen Jungpleistozän - Ein kritischer Beitrag. Rahden/Westf. : Marie Leidorf GmbH, 255 p., ill.

UCKO P.J., ROSENFELD A. 1967 - Palaeolithic Cave Art. London : Weidenfeld and Nicolson, 256 p., ill. 
